\title{
Margaret Wrong Memorial Fund: Award for 1958
}

THE Margaret Wrong Prize and Medal for 1958 have been awarded to the Abbe Alexis Kagame, the Ruanda poet, philosopher, and historian. He is a member of the Académie Royale des Sciences Coloniales (Brussels) and of the Belgian Commission de Linguistique Africaine and the author of a two-volume history of Ruanda, an account of the work of Leopold II and Cardinal Lavigetie in Central Africa, anthologies of Ruanda poetry, and an epic poem Isoko y Amayyambere. His best-known work in French is La Philosophic banturwandaise de l'Être-originally presented as a doctoral thesis to the Gregorian Pontifical University of Rome. The Abbé is at present engaged on an epic poem in Kinyaruanda on the story of the Creation and of Christianity, of which two parts have already been published in his own French translation.

It is understood that the presentation of the prize will be made in Ruanda this summer.

\section{Harvard Peabody Museum Film of the South African Bushmen-' The Hunters'}

THE Peabody Museum of Harvard University announces the release and general distribution of 'The Hunters ', a 71 -minute film, the first of a series to be produced by the Peabody Museum Film Study Center, which will give a comptehensive account of the South African Bushmen. The pictures were taken by the Peabody Museum of Harvard UniversitySmithsonian Institution Kalahari Expeditions, over the period 1950-8.

Arrangements may be made for the purchase or rent of the film, in colour or black and white, by writing to Contemporary Films, Inc., 267 West 25 th Street, New York I, New York.

\section{Publications of the Peabody Museum, Harvard University}

THE Harvard African Studies Series, published by the Peabody Museum, includes the five volumes of Varia Africana which appeared in 1917, 1918, 1922, 1928, and 1932 respectively. They contain studies by C. G. and B. Z. Seligman, Alice Werner, E. Cerulli, and others, covering a wide range of subjects and areas. Other volumes in the African Studies Series, including Reisner's Excavations at Kerma, Coon's Tribes of the Rif, and Murray's EnglishNubian Comparative Dictionary, are also available. The Peabody Museum, Cambridge 38, Mass., will be glad to send a complete publications list on request.

\section{Conference of African and Asian Writers at Tashkent (Uzbekistan)}

A CONFERENCE of African and Asian writers was held from 7 th to 13 th October at Tashkent and was attended by about 200 representatives from African and Asian countries and by leading members of the Soviet Union of Writers. The agenda for general discussion were: (i) the development of literature and culture and their place in the struggle for national independence, peace and freedom, and against colonialism; (ii) the cultures of the peoples of Asia and Africa and their links with Western culture. The conference was reported in Pravda, and Literaturnata Gazeta, and the latter contains an article by B. Matip, a Cameroons representative, on writers of 'Black Africa' in which the work of Amos Tutuola, Eza Boto, Mongo Bati, Ferdinand Ojono, Benjamin Matip and others is discussed. A permanent bureau was constituted and it is planned to establish an Afro-Asian publishing house and 2 monthly literary organ. The next meeting has been arranged for 1960 in Cairo. 